\title{
roscopy in leprosy*
}

\author{
Adma Silva de Lima ${ }^{1}$ \\ Scheila Fritsch ${ }^{2}$ \\ Fabiane Andrade Mulinari-Brenner ${ }^{2}$ \\ Vanessa Cristhine Dalombo Ottoboni ${ }^{2}$
}

\author{
Vanessa Irusta dal Pizzol ${ }^{2}$ \\ Gabriela Poglia Fonseca ${ }^{2}$ \\ Carolina de Souza Muller ${ }^{2}$
}

DOI: http:/ /dx.doi.org/10.1590/abd1806-4841.20164814

Abstract: Due to mounting evidences of interaction between Hansen's bacilli with endothelial cells and the paucity of studies addressing the presence of nailfold capillaroscopic alterations in patients with Hansen's disease, a study was carried out in order to verify the presence of capillaroscopic alterations in patients with leprosy in its various forms and its correlation with clinical parameters. Ten patients were evaluated at a specialized university service. Sixty percent of those had some capillaroscopic change, such as micro-hemorrhages, ectatic, bushy and corkscrew capillaries. Such changes were unspecific, which suggests there is not a specific pattern for this disease.

Keywords: Leprosy; Leprosy, borderline; Leprosy, lepromatous; Leprosy, Multibacillary;Leprosy, paucibacillary; Leprosy, tuberculoid; Mycobacterium leprae

Leprosy is a chronic infectious contagious disease, caused by Mycobacterium leprae or Mycobacterium lepromatosis, endemic in regions such as Sub-Saharan Africa, Asia, Central and South America, affecting millions of people. ${ }^{1}$ Brazil is placed second worldwide in number of cases, after India. ${ }^{2}$

The spectrum of the disease's involvement depends on the host's resistance to the bacillus and immune system action, which will also give rise to hansenic reactions. ${ }^{2}$

The organs classically involved are skin and peripheral nervous system, which may suffer permanent sequelae. The bacilli tend to be more prominent in colder regions and there is proof of its presence in the human nail bed. ${ }^{3}$ In the last decades, in animal models, it has been possible to demonstrate that the M. leprae may interact primarily with endothelial cells of vasa nervorum to, later, invade the endoneurum. ${ }^{4}$ Vascular phenomena, such as Lucio's phenomenon and phlebitis lepromatosa, have also been long known. ${ }^{5,6}$

Nailfold capillaroscopy (NC) is the evaluation in vivo of the nailfold microvascular network, a non-invasive and easily performed examination, with good reproducibility and correlation with anatomopathological findings. ${ }^{7}$ It has broad application in systemic rheumatic diseases, mainly in systemic sclerosis. However, in spite of evidences of interaction between M. leprae and endothelial cells, works demonstrating capillaroscopic findings in patients with leprosy are scarce.

In this study, NC examination was carried out in patients carrying leprosy being followed-up in a Dermatology Service of a university hospital, with the goal of verifying if there are capillaroscopic changes in this group of patients and if there is correlation with clinical forms and reactional states. Ten patients being regularly followed-up at the Dermatology and Leprosy Service of a university hospital were selected. They were clinically evaluated considering their sex, age, origin, educational level, age of disease, form of disease (tuberculoid, dimorphic, Virchow's), previous or current treatments, complications, hansenic reactions and their types, nail alterations, functional evaluation, use of drugs and comorbidities.

NC examination was performed by a single trained operator, according to previous scheduling of the patients, with an Olympus SZ40 stereomicroscope, as per standard protocol, described by Fonseca et al. in a previous study. ${ }^{8}$

The group of patients was composed of 5 men and 5 women. Ages varied from 36 to 70, with an average of 54.4. Patients originated, in their majority, from the countryside of Parana state. Two

Received on 08.06 .2015

Approved by the Advisory Board and accepted for publication on 10.10.2015

* Work performed at Hospital de Clínicas da Universidade Federal do Paraná (UFPR) - Curitiba (PR), Brazil.

Financial Support: None.

Conflict of Interest: None.

Universidade Regional de Blumenau (FURB) - Blumenau (SC), Brazil.

2 Universidade Federal do Paraná (UFPR) - Curitiba (PR), Brazil.

C2016 by Anais Brasileiros de Dermatologia 
patients had lived in the state of Rondonia. As for the clinical form of the disease, $30 \%$ of the patients presented Virchow's leprosy; $20 \%$, dimorphic leprosy; $40 \%$, tuberculoid leprosy; and $10 \%$ the indeterminate form. Half of the patients received multibacillary treatment, according to the current norms of Brazil's Ministry of Health. Five patients (50\%) developed hansenic reaction, all multibacillary. Out of these, reaction type 2 and neuritis occurred in $80 \%$ of the cases; reaction type 1 occurred in only 1 patient ( $20 \%$ of this sample).

Nail changes were found in $60 \%$ of the patients. The deformities found were: pitting, Beau's lines, onycholysis, onychorrhexis, splinter hemorrhages and pterygium. The most frequent changes were Beau's lines, splinter hemorrhages and onycholysis, found in a rate of $20 \%$ each.

Most patients presented functional evaluation grade I, that is, decreased sensitivity in hands and/or feet. The most frequent comorbidity was systemic arterial hypertension, in $30 \%$ of the patients.

At the nailfold capillaroscopy examination, $60 \%$ of the patients presented some capillaroscopic change, such as micro-hemorrhages, ectatic and corkscrew capillaries. The most frequent changes found were ectatic capillaries and micro-hemorrhages, in $40 \%$ of the patients. Greater capillary ectasies (megacapillaries) or capillary dropout areas were not found.

\section{REFERENCES}

1. .Han XY, Sizer KC, Velarde-Félix JS, Frias-Castro LO, Vargas-Ocampo F. The Leprosy Agents Mycobacterium lepromatosis and Mycobacterium leprae in Mexico. Int J Dermatol. 2012;51:952-9.

2. Penna GO, Pinheiro AM, Nogueira LSC, Carvalho LR, Oliveira MBB, Carreiro VP. Clinical and epidemiological study of leprosy cases in the University Hospital of Brasilia: 20 years - 1985 to 2005. Rev Soc Bras Med Trop. 2008;41:575-80.

3. Kato LE, Nakandakar S. Alterações ungueais especificas da hanseníase. Hansen Int. 1998;23:59-63.

4. Scollard DM, McCormick G, Allen JL. Localization of Mycobacterium leprae to Endothelial Cells of Epineurial and Perineurial Blood Vessels and Lymphatics. Am J Pathol. 1999;154:1611-20.

5. Thompson AM, Lynn AA, Robson K, Joyce MP, Fivenson DP, Scollard D. Lepromatous phlebitis of the external jugular vein. J Am Acad Dermatol. 2003:49:1180-2.

6. Pereira Jr AC. Hanseníase de Lúcio. An Bras Dermatol. 1993;68:33-40

7. Da Silva LSM, Lima ARAG, Pucinelli MLC, Atra E, Andrade LEC. Capilaroscopia panorâmica periungueal e sua aplicação em doenças reumáticas. Rev Ass Med Brasil. 1997:43:69-73

8. Fonseca GP, Brenner FM, Muller CS, Wojcik AL. Uso da capilaroscopia ungueal como método diagnóstico e prognóstico de rosácea. An Bras Dermatol. 2011;86:87-9

9. Lee P, Leung FY, Alderdice C, Armstrong SK. Nailfold capillary microscopy in the connective tissue diseases: a semiquantitative assessment. J Rheumatol. 1983;10:930-8.

10. Bartosisnka J, Chodorowska G. Original proposal of capillaroscopic images classification in psoriasis vulgaris and psoriatic arthritis Post Dermatol Alergol 2009;1:17-24
As to the clinical forms, 2 patients with tuberculoid leprosy, 2 with borderline leprosy and 1 with Virchow's and indeterminate forms, respectively, presented changes through the capillaroscopy. Both patients with functional evaluation grade I and grade 0 presented capillaroscopic changes. Among the patients with detectable capillaroscopic , $66.7 \%$ presented nail alterations; in patients without capillaroscopic changes, $33 \%$ presented some nail alteration detectable at the physical examination.

Nailfold capillaroscopy is a non-invasive method, which is an evaluation in vivo of the nailfold microvascular network. ${ }^{7,9}$ Several diseases in which there are changes in microcirculation may benefit from capillaroscopy. ${ }^{7,8,9}$

Among cutaneous diseases, in recent years, several studies have evaluated the nailfold microvascular network in patients with psoriasis, finding evidences of changes in those with psoriatic arthritis and nail involvement. ${ }^{10}$ Notwithstanding, in other diseases with vascular changes, such as rosacea, recent studies did not demonstrate the presence of specific patterns. ${ }^{8}$

The involvement of endothelial cells by the bacillum could justify changes in cutaneous capillaries, which are analyzed during capillaroscopy. Yet, in this study, specific capillaroscopic patterns of leprosy were not detected in the cases. The changes detected suggest microtraumatic etiology and occurred both in patients with normal and altered functional evaluation. $\square$

How to cite this article: de Lima AS, dal Pizzol VI, Fritsch S, Fonseca GP, Mulinari-Brenner FA, Muller CS, Ottoboni VCD. Nailfold capillaroscopy in leprosy. An Bras Dermatol. 2016;91(5):686-7. 